\title{
The COVID-19 Crises: Healthcare Resource Management Strategies
}

\author{
(1) Muhammad Akbar Baig ${ }^{1}$, (1) Samia Kazmi² \\ 1Department of Emergency Medicine, Aga Khan University Hospital, Karachi, Pakistan \\ 2Department of Internal Medicine, The Indus Hospital, Karachi, Pakistan
}

\section{Dear Editor,}

The recent pandemic of coronavirus disease-19 (COVID-19) poses an immense challenge to the response capacity of healthcare systems worldwide especially of low and low to middle income nations. To ensure that COVID-19 patients can access healthcare facilities without compromising the safety of health care workers, we propose key action steps that may be undertaken in less resourceful settings in order to enable necessary and timely clinical operations.

With available data from China, $40 \%$ of COVID-19 patients had mild symptoms not requiring hospital admission, 40\% developed moderate symptoms requiring hospital admission, $15 \%$ had severe disease requiring oxygen therapy and inpatient intervention and $5 \%$ were critical requiring invasive ventilation and intensive care unit admission (1). However, with the recent outbreak in other nations, there was a larger proportion of severe and critically ill COVID-19 patients indicating a dire need to rapidly increase surge capacity for preventing exhaustion of health care resources (2).

Presently, countries already are responding rapidly to the pandemic while ensuring modification to their approaches which are relevant to their local context. They most likely are or will have to deal with cases ranging from massive outbreaks to clusters developing sporadically through local/acquired infection (3).

We believe that in the event of surge, there is a need for multiple COVID-19 treatment areas. Two essential treatment areas will always remain to be hospitals that will serve as dedicated COVID-19 units (C-19U) consisting of triage and inpatient (ward and intensive care unit) service and the primary health centers which will serve as COVID-19 Satellite (C-19S) zones consisting of triage and temporary treatment rooms. Both areas will be connected via a robust referral system along with emergency medical services for transport of moderate to critically ill cases from C-19S to C-19U if required (4).

We suggest the following grid for ease of understanding which will help us divide COVID-19 cases into all possible presentations along with disposition strategies for each.

\begin{tabular}{|l|l|l|}
\hline & COVID-19 positive & COVID-19 suspected \\
\hline Stable & $\begin{array}{l}\text { Stable and confirmed } \\
\text { (A) }\end{array}$ & $\begin{array}{l}\text { Stable and suspected } \\
\text { (B) }\end{array}$ \\
\hline Unstable & $\begin{array}{l}\text { Unstable and confirmed } \\
\text { (C) }\end{array}$ & $\begin{array}{l}\text { Unstable and suspected } \\
\text { (D) }\end{array}$ \\
\hline
\end{tabular}

On the basis of above, the cases can be designated as a "cold" COVID-19 patient (not requiring admission) and a "hot" COVID-19 patient (requiring management) as discussed in following detail below;

\begin{tabular}{|l|l|}
\hline Cold Covid-19 & Hot Covid-19 \\
\hline $\begin{array}{l}\text { A = No admission needed. Offer } \\
\text { symptomatic therapy with and } \\
\text { counsel for home quarantine } \\
\text { measures }\end{array}$ & $\begin{array}{l}\text { C= Admission for COVID-19 } \\
\text { testing and management }\end{array}$ \\
\hline $\begin{array}{l}\text { B = No admission needed. Advise } \\
\text { COVID-19 testing, offer symptomatic } \\
\text { therapy and counsel for home } \\
\text { quarantine measures }\end{array}$ & $\begin{array}{l}\text { D=Admission for COVID-19 } \\
\text { testing and management }\end{array}$ \\
\hline
\end{tabular}

We advise that all relevant stakeholders must continue to ensure basic safety of health care staff by providing personal protective gear and biomedical equipment (oxygen, ventilators etc.) including contingency plans for shortages in supplies. 
There should be adequate laboratory facilities with defined testing strategies in the event of a surge. Strict policies should be enforced to restrict visitor entry in designated treatment zones and public movement in order to prevent community spread. Debriefing measures should be performed frequently in order to highlight and implement modifications as per perceived experiences (5).

Keywords: COVID-19, SARS CoV-2, Novel corona virus, emergency, crises

\section{Ethics}

Peer-review: Externally and internally peer-reviewed.

\section{Authorship Contributions}

Concept: M.A.B., S.K., Design: M.A.B., S.K., Data Collection or Processing: M.A.B., S.K., Analysis or Interpretation: M.A.B., S.K., Literature Search: M.A.B., S.K., Writing: M.A.B., S.K.

Conflict of Interest: No conflict of interest was declared by the authors.
Financial Disclosure: The authors declared that this study received no financial support.

\section{References}

1. Wu Z, McGoogan JM. Characteristics of and important lessons from the coronavirus disease 2019 (COVID-19) outbreak in China: summary of a report of 72314 cases from the Chinese Center for Disease Control and Prevention. JAMA. 2020;323:1239-42

2. Hasan Z, Narasimhan M. Preparing for the COVID-19 pandemic: our experience in New York. Chest. 2020;157:1420-2.

3. World Health Organization. Critical preparedness, readiness and response actions for COVID-19 2020 (updated 23 March 2020 cited 202016 June). Available from: https://www.who.int/publications-detail/criticalpreparedness-readiness-and-response-actions-for-covid-19

4. Norton I, Schreeb Jv, Aitken P, Herard P, Lajolo C. Classification and minimum standards for foreign medical teams in sudden onset disasters: World Health Organization; 2013 (cited 202016 June). Available from: https://www.who. int/csr/resources/publications/ebola/foreign-medical-teams/en/

5. World Health Organization. Operational considerations for case management of. COVID-19 in health facility and community 2020 (updated 19 March 2020; cited 202016 June). Available from: https://apps.who.int/iris/bitstream/ handle/10665/331492/WHO-2019-nCoV-HCF_operations-2020.1-eng.pdf 